\title{
Should Indian researchers pay to get their work published?
}

\author{
Muthu Madhan*, Siva Shankar Kimidi, Subbiah Gunasekaran and Subbiah Arunachalam
}

Paying to publish is an ethical issue. During 2010-14, Indian researchers have used 488 open access (OA) journals levying article processing charge (APC), ranging from US\$ 7.5 to 5,000, to publish about 15,400 papers. Use of OA journals levying APC has increased from 242 journals and 2,557 papers in 2010 to 328 journals and 3,634 papers in 2014. We estimate that India is potentially spending about US\$2.4 million annually on APCs paid to OA journals and the amount would be much more if we add APCs paid to make papers published in hybrid journals open access. It would be prudent for Indian authors to make their work freely available through interoperable repositories, a trend that is growing in Latin America and China, especially when funding is scarce. Scientists are ready to pay APC as long as institutions pay for it and funding agencies are not ready to insist that grants provided for research should not be used for paying APC.

Keywords: Article processing charge, hybrid OA journals, institutional repositories, OA policy, open access journals.

MORE than two decades ago, Harnad posted his subversive proposal to a mailing list in which he called on researchers 'to make copies of all the papers they published in scholarly journals freely available on the internet ${ }^{1,2}$. Many researchers now make their papers freely available either by publishing them in open access (OA) journals, or by placing them in repositories or websites. Indeed, a 2013 report asserted that by 2011 'free availability of a majority of papers has been reached in general science and technology, in biomedical research, biology, and mathematics, and statistics', and that the number of OA papers has been growing by about $2 \%$ a year ${ }^{3}$.

Journals make papers open access in two ways: OA journals make all papers open access immediately on publication, and hybrid OA journals make selected papers open access. Most OA journals listed in the Directory of Open Access Journals (DOAJ) do not charge to make a paper open access. Current Science is one such journal. Many OA journals - about 26\% according to Solomon and Björk ${ }^{4}$ - and all hybrid OA journals levy an article processing charge (APC) to provide OA to a paper. However, according to Crotty ${ }^{5}$, the majority of OA papers are published by paying an APC. The APC levied by journals

Muthu Madhan and Subbiah Arunachalam are in the DST Centre for Policy Research, Archives and Publication Cell, Indian Institute of Science, Bengaluru 560 012, India; Siva Shankar Kimidi is in the Library, Indian Institute of Technology Hyderabad, Kandi, Sangareddy 502 285, India; Subbiah Gunasekaran is in the Knowledge Resource Centre, Central Elecrochemical Research Institute, Karaikudi 630003 , India; Subbiah Arunachalam is also in the Centre for Internet and Society, Bengaluru 560 071, India.

*For correspondence. (e-mail: mu.madhan@gmail.com) used by Indian researchers is in the range INR $500(\sim$ US\$ 8)-US\$ 5000.

OA journal publishing, particularly by commercial publishers and in the field of biomedicine, is growing rapidly. According to DOAJ, as of 2 September 2016, there are 9192 OA journals published from 130 countries and one can access more than 2.27 million articles. Currently, DOAJ is growing at a net rate of six titles per day $^{6}$. The Directory of Open Access Scholarly Resources (ROAD) lists 14,031 OA journals published from about 140 countries $^{7}$.

Repositories, where full texts of research publications are deposited and made available on-line, are of two kinds: (i) central repositories, such as arXiv and Social Science Research Network (SSRN), and (ii) distributed (or institutional) repositories, such as the University of Southampton institutional research repository, eprints.soton.ac.uk.

Here we are concerned only with the OA journals which make all content open access immediately on publication. Further, our interest is in papers from India that are published in journals levying APC. The question we are particularly interested in is as follows: 'is paid open access affordable for India?'And, even if it is affordable, should we go for it?

We assessed the current status of use of OA journals by Indian researchers using bibliometric analysis of data gathered from the Web of Science (WoS) - Science Citation Index Expanded (SCIE). We used this analysis to obtain the number of papers Indian researchers have published in OA journals charging APC, leading to an estimate of the amount the country as a whole would have 
potentially spent on APC costs, and to observe if publishing in paid $\mathrm{OA}$ journals led to higher number of citations.

\section{Methodology}

We searched for articles, letters, proceedings papers and reviews from India in OA journals indexed in SCIE in the five years, 2010-14. The search made on 11 January 2016 resulted in 37,122 papers. Among these, 44 papers resulting from five international collaborations (CMS, ATLAS, ALICE, STAR and FAITH), and appearing in journals such as Physics Letters B, New Journal of Physics, Nuclear Physics B and BMC Musculoskeletal Disorders, had a very large number of authors (running to several hundreds). We removed them from the dataset as they hindered processing of the data. Thus, we considered 37,078 papers. We downloaded full bibliographic data for all these and analysed them using Visual FoxPro. We found that Indian researchers have used 881 OA journals to publish these papers. We visited the website of each of these journals during January and February 2016 to obtain information on APC levied by them. Also, we classified the journals into 22 major field categories following the Essential Science Indicators (ESI) classification. This classification does not allocate journals to multiple fields. We identified papers in which at least one author was from a country other than India.

Using the same strategy as used for Indian publications, we recorded the number of papers published by 12 other countries and the proportion of OA papers (data gathered on 29 January 2016).

\section{Results}

We present here the most important findings. Details of our bibliometric analysis are available from the authors and will soon be presented in a report.

\section{Use of OA journals by researchers}

In the five years considered, SCIE had indexed 6,460,105 papers, of which 748,127 (or $11.58 \%$ ) were in OA journals. Figure 1 presents the share of journal publications which have appeared in OA journals in 13 countries in the 5-year period, 2010-2014. Brazil has the highest proportion (close to one in three papers), with India coming a distant second (one in seven papers). That Brazil leads is not surprising. Long before the OA movement began, the funding community led by the São Paulo Science Foundation (FAPSEP) and the information community led by the Latin American and Caribbean Center on Health Sciences Information recognized the need for strengthening the visibility of the Brazilian journals, and initiated the SciELO movement in São Paulo, in 1997, which later spread to Chile and the rest of Ibero-America and South Africa ${ }^{8}$. As pointed out by Vessuri et al. $^{9}$, a strong sense of public mission among Latin American universities, coupled with the realization that OA improves the presence and impact of their research publications led Latin America to develop its own knowledge exchange mechanisms on its own terms.

Estimates of the proportion of OA papers vary widely, depending on the source used and when the estimate is made. For example, by analysing journals indexed in Scopus we found that 4231 of the 22,460 active titles (as of 6 February 2016) were OA (as seen from DOAJ on September 2015), and were listed in either or both of DOAJ and ROAD ${ }^{10}$. Of the more than 12,000 journals covered by WoS, 1313 are OA as of October 2015 as listed by $\mathrm{DOAJ}^{11}$. Analysing data from Google Scholar, Jamali and Nabavi ${ }^{12}$ showed that more than $61 \%$ of papers were accessible in full text.

\section{Use of journals charging APC}

In 2010, Indian researchers had published their work in 479 OA journals, of which 237 did not charge APC. The number of OA journals used by Indian researchers to publish their work is increasing (Table 1). It rose from 445 in 2009 (ref. 13) to 611 in 2014. More than half of the 611 journals levy APC.

Not all journals charging APC have a fixed amount; there are many models. Of the 881 SCIE-indexed OA journals which Indian researchers have used, 488 charge a fee: 437 charge a fixed APC, 49 levy page charges, and two charge a non-refundable submission fee. Contrary to Crotty's observation that the majority of OA papers are published by paying an $\mathrm{APC}^{5}$, Indian authors publish a larger number of papers in non-APC journals. However, papers published in journals levying APC are cited more times on average.

The APC OA journal used most often by Indian researchers in the 5-year period is PLoS One, with a total publication count of 2404 and average cites per paper (CPP) or citation rate of 7.32. Starting with 78 papers in 2009 from India (ref. 13), the number increased to 724 papers in 2014. Indeed, Current Science, which comes next in the list with 2334 papers and with a CPP of 1.74 , was the leader until 2011.

\section{Overseas collaboration}

All authors are from India in 30,152 of the 37,078 papers published by Indian researchers in the 881 OA journals. This includes papers in which all authors are from the same institution, as well as those with authors from more than one Indian institution. These papers have been cited 78,722 times with a CPP of 2.61. There are 6926 papers with at least one author from an address outside India, 


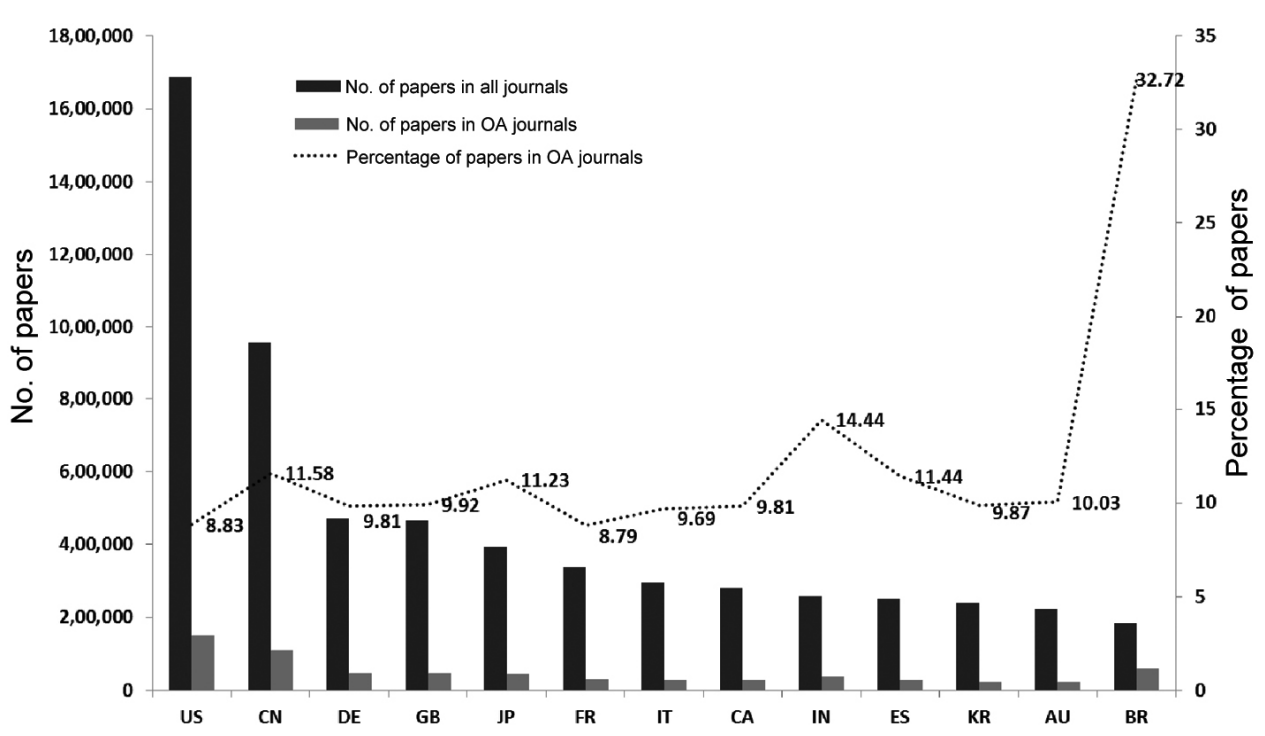

Figure 1. Share of papers published by different countries in open access (OA) journals indexed in Science Citation Index Expanded, 2010-2014 (Only articles, letters, proceedings papers, and reviews are considered). Data gathered on 29 February 2016. Great Britain includes England, Scotland, Wales and

Northern Ireland.

Table 1. Distribution of research papers published by Indian scientists in open access $(\mathrm{OA})$ journals by publishing year

\begin{tabular}{|c|c|c|c|c|c|c|c|c|c|}
\hline \multirow[b]{2}{*}{ Year } & \multicolumn{3}{|c|}{ OA journals (APC) } & \multicolumn{3}{|c|}{ OA journals (non-APC) } & \multicolumn{3}{|c|}{ All OA journals } \\
\hline & $\begin{array}{l}\text { No. of } \\
\text { journals }\end{array}$ & $\begin{array}{l}\text { No. of } \\
\text { papers }\end{array}$ & $\begin{array}{l}\text { Sum of } \\
\text { citations }\end{array}$ & $\begin{array}{l}\text { No. of } \\
\text { journals }\end{array}$ & $\begin{array}{l}\text { No. of } \\
\text { papers }\end{array}$ & $\begin{array}{l}\text { Sum of } \\
\text { citations }\end{array}$ & $\begin{array}{l}\text { No. of } \\
\text { journals }\end{array}$ & $\begin{array}{l}\text { No. of } \\
\text { papers }\end{array}$ & $\begin{array}{l}\text { Sum of } \\
\text { citations }\end{array}$ \\
\hline 2010 & 242 & 2557 & 17,550 & 237 & 4131 & 16,301 & 479 & 6688 & 33,851 \\
\hline 2011 & 263 & 3067 & 17,367 & 244 & 4280 & 12,645 & 507 & 7347 & 30,012 \\
\hline 2012 & 308 & 2800 & 15,715 & 251 & 4157 & 9276 & 559 & 6957 & 24,991 \\
\hline 2013 & 326 & 3335 & 12,635 & 268 & 4457 & 6257 & 594 & 7792 & 18,892 \\
\hline 2014 & 328 & 3634 & 6950 & 283 & 4660 & 3057 & 611 & 8294 & 10,007 \\
\hline Total & & 15,393 & 70,217 & & 21,685 & 47,536 & & 37,078 & 117,753 \\
\hline
\end{tabular}

Data gathered on 11 January 2016.

and these have been cited 39,031 times with a CPP of 5.63. Indian researchers have collaborated with authors from some 115 countries. Collaborators are mainly from USA (2191 papers), UK (815 papers) and Germany (708 papers).

\section{Country of journal publication}

Indian authors have published in OA journals from 61 countries. More than half $(18,781)$ were published in 48 Indian journals, 6 of which charge APC. As one would expect, US and UK journals followed Indian journals in the number of papers published: 7647 papers were published in 149 US journals of which 107 charge APC, and 2834 papers were published in 172 UK journals of which 162 charge APC. Indian researchers have published 675 papers in 54 Brazilian OA journals of which nine levy APC, 229 papers in nine Chilean OA journals of which two levy APC, 231 papers in 14 journals published from
China of which 5 charge APC in the 5-year period. In these five years Indian authors have published 652 papers in 7 Nigerian APC journals. Of these, all but one were delisted from WoS after a few years of coverage. Such delisting is common. Of the 881 journals studied here, only 263 have been used by Indian researchers in all the five years.

\section{Citations to papers published in journals levying $A P C$}

Table 2 lists the papers by Indian researchers in 57 journals charging APC and publishing at least 10 papers from India. Table 3 lists the 10 journals that do not levy APC and have been cited at least 10 times on average in the five years. Three journals, viz. Nucleic Acids Research, PLoS Neglected Tropical Diseases, and BMC Genomics, all of which charge an APC of well over US\$2000, have published more than 100 papers from India. In all three 
Table 2. OA journals which levy APC in which Indian authors have published at least 10 papers that have been cited not less than 10 times on average in the five years

\begin{tabular}{|c|c|c|c|c|c|}
\hline Journal & $\begin{array}{l}\text { Publishing } \\
\text { country* }\end{array}$ & $\begin{array}{l}\text { No. of } \\
\text { papers }\end{array}$ & $\begin{array}{l}\text { Sum of } \\
\text { citations }\end{array}$ & $\mathrm{CPP}^{\dagger}$ & $\mathrm{APC}$ \\
\hline Nucleic Acids Research & GB & 138 & 1945 & 14.09 & US\$ 2770 \\
\hline PLoS Neglected Tropical Diseases & US & 126 & 1409 & 11.18 & US\$ 2250 \\
\hline BMC Genomics & GB & 123 & 1330 & 10.81 & US\$ 2145 \\
\hline International Journal of Nanomedicine & NZ & 94 & 1555 & 16.54 & $€ 1843$ \\
\hline Atmospheric Chemistry and Physics & $\mathrm{DE}$ & 65 & 1116 & 17.17 & $€ 25^{\#}$ \\
\hline BMC Plant Biology & GB & 44 & 579 & 13.16 & US\$ 2145 \\
\hline PLoS Pathogens & US & 42 & 781 & 18.60 & US\$ 2250 \\
\hline Molecular Cancer & GB & 34 & 540 & 15.88 & US\$ 2145 \\
\hline International Journal of Molecular Sciences & $\mathrm{CH}$ & 28 & 298 & 10.64 & CHF 1600 \\
\hline Molecules & $\mathrm{CH}$ & 28 & 300 & 10.71 & CHF 1800 \\
\hline PLoS Computational Biology & US & 25 & 342 & 13.68 & US\$ 2250 \\
\hline PLoS Medicine & US & 25 & 721 & 28.84 & US\$ 2900 \\
\hline DNA Research & GB & 24 & 542 & 22.58 & US\$ 750 \\
\hline PLoS Genetics & US & 24 & 354 & 14.75 & US\$ 2250 \\
\hline Biogeosciences & DE & 23 & 294 & 12.78 & $€ 25^{\#}$ \\
\hline $\begin{array}{l}\text { International Journal of Environmental Research and } \\
\quad \text { Public Health }\end{array}$ & $\mathrm{CH}$ & 22 & 278 & 12.64 & CHF 1600 \\
\hline Journal of Translational Medicine & GB & 15 & 238 & 15.87 & US\$ 2145 \\
\hline Marine Drugs & $\mathrm{CH}$ & 14 & 256 & 18.29 & CHF 1800 \\
\hline Journal of Neuroinflammation & GB & 12 & 179 & 14.92 & US\$ 450 \\
\hline Science and Technology of Advanced Materials & GB & 12 & 181 & 15.08 & US\$ 1600 \\
\hline BMC Medicine & GB & 11 & 374 & 34.00 & US\$ 2785 \\
\hline Remote Sensing & $\mathrm{CH}$ & 11 & 125 & 11.36 & CHF 1600 \\
\hline Cryosphere & $\mathrm{DE}$ & 10 & 112 & 11.20 & $€ 25^{\#}$ \\
\hline Progress in Electromagnetics Research & US & 10 & 128 & 12.80 & US\$ 200 \\
\hline Articles in 33 other journals with CPP $>10$ & & 117 & 1930 & 16.50 & \\
\hline Total & & 1077 & 15,907 & & \\
\hline
\end{tabular}

*ISO 3166 country code. ${ }^{*}$ Page charges. ${ }^{\dagger} \mathrm{CPP}$, Cites per paper.

Table 3. Non-APC journals in which Indian authors have published their papers that have been cited not less than 10 times on average in the five years

\begin{tabular}{lcccc}
\hline Journal & $\begin{array}{c}\text { Publishing } \\
\text { country* }\end{array}$ & $\begin{array}{c}\text { No. of } \\
\text { papers }\end{array}$ & $\begin{array}{c}\text { Sum of } \\
\text { citations }\end{array}$ & CPP \\
\hline Bulletin of the World Health Organization & CH & 41 & 515 & 12.56 \\
Journal of Pharmacy and Pharmaceutical Sciences & CA & 14 & 173 & 12.36 \\
Environmental Health Perspectives & US & 10 & 188 & 18.80 \\
Journal of Machine Learning Research & US & 10 & 118 & 11.80 \\
Materials Today & GB & 4 & 81 & 20.25 \\
Earth System Science Data & DE & 3 & 88 & 29.33 \\
Revista Mexicana de Astronomia Y Astrofisica & MX & 3 & 181 & 60.33 \\
Revista Mexicana de CienciasGeologicas & MX & 3 & 41 & 13.67 \\
Folia Neuropathologica & PL & 2 & 23 & 11.50 \\
Upsala Journal of Medical Sciences & GB & 2 & 20 & 10.00 \\
\hline
\end{tabular}

*ISO 3166 country code.

journals, CPP of Indian papers is less than that of the journal as a whole, and there is a big difference between the CPP of papers written solely by Indian authors and of those written in collaboration with foreign authors. For example, Nucleic Acids Research has published 138 papers from India (CPP 14.09), out of a total of 6614. The average CPP of the journal for the 5-year period is 25.29 , as against India's CPP of 14.09 . The 80 papers, entirely written by Indian researchers have a CPP of less than 10 , and the CPP of the 58 papers with foreign collaborators is more than 22 .

As many as 92 papers have appeared in $10 \mathrm{OA}$ journals which do not charge APC, none of which is from India, and these have been cited more than 15 times on average. Of the 92 papers, 41 were published in the Bulletin of the World Health Organization with a CPP of about 12.5. In contrast, CPP of the 478 papers published in the journal during the five years is above 15 . 
GENERAL ARTICLES

Table 4. Mega journals used by Indian researchers

\begin{tabular}{lcrrrr}
\hline Journal & $\begin{array}{c}\text { Publishing } \\
\text { country* }\end{array}$ & $\begin{array}{c}\text { No. of } \\
\text { papers }\end{array}$ & $\begin{array}{c}\text { Sum of } \\
\text { citations }\end{array}$ & CPP & APC \\
\hline PLoS One & US & 2404 & 17,587 & 7.32 & US\$1495 \\
Scientific Reports & GB & 222 & 1523 & 6.86 & $£ 990$ \\
AIP Advances & US & 196 & 645 & 3.29 & US\$1350 \\
SpringerPlus & GH & 170 & 235 & 1.38 & US\$1290 \\
BMJ Open & GB & 56 & 148 & 2.64 & $£ 1,350$ \\
FEBS Open Bio & GB & 21 & 86 & 4.10 & US\$1350 \\
PeerJ & GB & 13 & 33 & 2.54 & US\$695 \\
Biology Open & GB & 9 & 9 & 1.00 & US\$1495 \\
G3-Genes Genomes Genetics & US & 9 & 83 & 9.22 & US\$1950 \\
\end{tabular}

*ISO 3166 country code.

\section{Use of mega journals}

Indian authors have published 3100 papers in 9 mega journals, where the papers are accepted without applying the usual standards of strict peer review if they are perceived to be technically sound (Table 4).

\section{Papers classified by field}

It is in Clinical Medicine that Indian researchers have published in the largest number of OA journals (208), as well as contributed the largest number of papers $(10,036)$. They have published in 88 journals in the field of plant and animal science, but have published a much larger number of papers in both chemistry, and biology and biochemistry in a smaller number of journals.

\section{Discussion}

Over $14.4 \%$ of the 37,122 papers from India as seen from SCIE have been published in OA journals. The actual number of OA papers from India will be much larger, since, for example, Scopus is likely to have indexed a larger number of such papers. Additionally, there are papers published in hybrid OA journals and those published in non-OA journals that are made open access by placing them in institutional or central repositories or freely available through author websites, which indicates that there is a welcome growing awareness of the need for making one's work OA. Our earlier study $^{13}$ has revealed that some $16 \%$ of Indian papers were published in OA journals indexed in SCIE 2009, but in that study we had considered all categories of papers from OA journals collected comprehensively from various sources.

\section{Potential expenditure on APC seen in perspective}

We estimated the total APC for all 14,293 papers published by Indian authors in OA journals charging a fixed amount (leaving out $7 \%$ of all OA papers charging variable APC). We found there is an average cost of $\sim$ US\$ 1173 per paper. We compared this figure with the costs on APC incurred by institutions elsewhere.

From a survey of a large sample of journals listed in DOAJ carried out in 2014, Morrison et al. ${ }^{14}$ reported an average APC of US\$ 964.

The Wellcome Trust, which supports payment of charges incurred by their grantees, reported a total spending of about $£ 4.7$ million paid for 2556 papers, published in OA or hybrid journals, in 2013-14 at an average APC of $£ 1837$. Close to $60 \%$ of these papers were published in the journals of five leading publishers, and among these $68 \%$ were in hybrid journals. In 2014-15, the Charity Open Access Fund, comprising the Wellcome Trust and five other funders, had paid more than $£ 5.6$ million towards APC for 2942 papers at an average cost of $£ 1914$ (ref. 15).

In its report dated March 2015, Research Councils UK (RCUK) indicated an average APC of $£ 1600$, based on charges paid for 6504 papers from 55 universities during the two years, 2013-14 and 2014-15. The average APC paid varies with university, from $£ 778$ for the School of Oriental and African Studies to £2248 for Durham University $^{16}$. Over the 15-month period, April 2013-July 2014, Leeds University alone had paid publishers a little over $£ 270,000$, of which about $£ 10,000$ was for colour and page charges. For the 166 RCUK-funded papers for which APC was paid during the review period, the average cost was $£ 1626.74$ (ref. 17). The University of Cambridge spent $£ 936,000$ towards APC in 2014. For the 495 RCUK-funded papers, the average cost was $£ 1891$ (ref. 18). Besides this, the University has also supported payment of page and colour page charges and has paid for researchers to join memberships that offer a discount for APC out of the RCUK fund. There is a growing concern in the universities if they should be spending so much money on $\mathrm{APC}^{18}$.

Björk and Solomon ${ }^{19}$, in their report submitted to a consortium of European funding agencies in March 2014, 
had estimated a 2-year average APC for journals indexed in Scopus at US\$ 1418.

Gerritsma $^{20}$ reported that in 2013 the Netherlands had spent $€ 4$ million towards 3314 papers published in OA journals charging APC. The expenditure on publications in hybrid journals indexed in SCIE, was estimated at an average APC of $€ 1220$ (ref. 20).

In 2015, the Austrian Science Fund (FWF) spent over $€ 418,000$ on APC for 288 papers in gold OA journals (average €2376) and €2.38 million on APC for 913 papers (average $€ 1453$ ). In addition, FWF incurred an expenditure of $€ 273,600$ on other costs ${ }^{21}$.

The variation is to be expected, as the sampled journals vary. In the case of India, a substantial number of lowAPC journals would have been used. Wang et al. ${ }^{22}$ have found that APC varies from region to region. European and North American APC OA journals have an average charge of more than US\$2000, while Asian, African and South American APC OA journals have an average charge of less than US\$ 1000 (ref. 22).

If we assume that money was paid in full for all the 14,297 papers (4775 with foreign collaborators and 9522 by exclusively Indian authors) published by Indian authors in OA journals charging APC, the total expenditure would be around US\$ 16.75 million. This figure does not include costs for the other $7 \%$ of papers published in journals charging APC on the basis of number of pages, submission fee, and so on. Nor does it include the expenditure on OA papers published in hybrid journals. These journals usually charge much more than those with fixed APC. According to Björk and Solomon ${ }^{19}$, the average APC for publication charged by hybrid journals published by subscription publishers (such as Elsevier and Wiley) is US\$ 2727 , almost double that charged by fully OA journals by non-subscription publishers (such as PLoS), US\$ 1418. It is possible that APC for many papers jointly authored with foreign collaborators might have been paid by the overseas participant. Also, in some cases authors might have been granted either a fee waiver or a discount. Allowing for these possibilities, we may assume that the sum spent would still be very high, more than $\sim$ US $\$ 12$ million, or an average of US\$ 2.4 million a year. This amount is in addition to the national expenditure on its academic and research library budget. Data released early in 2016 as part of the National Institutional Ranking Framework (https://www.nirfindia.org/Ranking) exercise reveal that the academic and library budget is by no means small.

\section{Failure of the 'author pays' model}

In the initial years of the 'author pays' OA journals, the hope was that OA publishing would be cheaper than subscription publishing. Eisen claimed that APC would go down 'and will continue to do so, asymptotically approaching zero, ${ }^{23}$. What we see in reality, however, is that the APC charged by PLoS One has gone up from US\$ 1250 when it was founded in December 2006 to US\$ 1450 now. The APC charged by PLoS Biology and PLoS Medicine has increased from US\$ 1500 at launch in 2003 to US\$ 2900 in 2012, a rise of $93 \%$ in nine years ${ }^{23}$. The situation at BioMed Central (BMC) is no different. Comparing the APC levied by the 165 BMC titles between 2010 and 2016, Wheatly ${ }^{24}$ has shown that for many titles there has been a substantial rise. A former employee of $P L o S$ had recently conceded that "no functional market is emerging and it (APC model) might be the wrong economic model, 25 .

When the high-energy physics community and librarians from more than 20 countries negotiated with publishers to make key journals $\mathrm{OA}$, the negotiation resulted in a contract with 11 publishers which would ensure that they could make 10 journals OA immediately on publication and, in return, they would continue to make profits as before with the subscription model. From its inception in January 2014, $\operatorname{SCOAP}^{3}$ (ref. 26) is making papers available on an OA basis and it levies an average APC of US\$ 1165 (ref. 26). According to Morrison ${ }^{6}$, 'SCOAP' (ref. 26) nearly doubled in size this past year $(87 \%$ annual growth) for a total of 4690 documents', and 'the Electronic Journals Library added 3612 journals that can be read free-of-charge in the past year, for a total of 52,000 journals, a 7\% growth rate'.

As early as 1999 , Rosenzweig ${ }^{27}$ pointed out that the world of knowledge was being 'kidnapped and held for ransom' by commercial publishers who have 'turned renegade, exiling themselves from the academic enterprise, and focusing entirely on making the most money for their stockholders' and in the process 'restricting the flow of knowledge'. Many commercial publishers are enlarging their OA business. Laakso and Björk ${ }^{28}$ have pointed out that today, OA papers are mostly published by commercial publishers and that the number of papers published by them has jumped from 13,400 in 2005 to 119,900 in 2011 (ref. 28). Björk and Solomon ${ }^{19}$ have shown that 'among the established OA publishers with journals listed in Scopus, the average APC grew by about 5\% a year over the two years 2012-2013'. Taking such increases into account, India's APC bill is bound to grow far beyond the US\$ 2.4 million in the future. These cost increases are unpredictable, making it difficult for organizations willing to pay APC to make appropriate provisions in their budgets.

\section{Affordable OA publishing}

Concerned about the high subscription costs and audience-limiting access rules of many traditional journals and the high APC charged by OA journals, many editorial boards broke away from publishers of such journals 'in 
order to launch a comparable journal with a friendlier publisher or less-restrictive access policy ${ }^{29}$. The most recent example is the en masse resignation of Johan Rooryck and other members of the editorial board of Lingua to start Glossa $a^{30}$. An early example was the resignation of the editor of Evolutionary Ecology along with many members of the editorial board in 1998 to start Evolutionary Ecology Research (ref. 29). Suber maintains a list of such 'Journal declarations of independence'29. Gow$\mathrm{ers}^{31}$, a strong opponent of publishers making tall claims about the value they add to publications and the huge subscription prices they charge, has launched an arXiv overlay journal called Discrete Analysis, owned by a group of researchers, in which the overall cost per article will be well below $\$ 30$ (ref. 31). His idea is to demonstrate that 'in the internet age, and in particular in an age when it is becoming routine for mathematicians to deposit their articles on the arXiv before they submit them to journals, the only important function left for journals is organizing peer review, ${ }^{31}$. How will these journals survive? Initially, the Association of Dutch Universities and The Netherlands Organization for Scientific Research will fund Glossa so that it can be completely free for both authors and readers, and the Open Libraries of the $\mathrm{Hu}$ manities will take over the funding after five years ${ }^{32}$. Seed money from the University of Cambridge will fund Discrete Analysis in the first five years ${ }^{31}$.

According to Gowers' 'its important (that these alternative models) acquire a reputation and prestige that people can feel it's okay to submit to them - rather than the more established traditional journals - without damaging their careers', ${ }^{32}$. 'We need an alternative, cheap system sitting there - at which point the commercial publishers will become redundant., ${ }^{33}$

\section{Should Indian researchers spend a large sum on APC?}

Why do authors choose to publish in certain journals? Scientists want their work not only to be seen and read, but also to be appreciated and cited. For them, publications are the culmination of their research and a means of achieving prestige and visibility. Moreover, the journals in which authors publish play an important role in the way the global community of scientists and funding agencies evaluate a scientist. Authors choose journals that would bring them maximum visibility, prestige and citations. Although there have been many discussions in recent times about the role of citations in scholarly communication and the undue importance paid to journal impact factors $(\mathrm{IF})^{34}$, scientists of all age groups look forward to their papers being cited repeatedly and quickly, and journals proudly advertise their IFs on their cover pages. Scientists do not really care if a journal is OA or if it levies APC (as long as their institution or fun- der is ready to cover the costs), nor surprisingly are they chary of surrendering all rights of their paper to the publisher. Many journals levying APC satisfy authors' expectations to a lesser or greater extent, and authors are able to find journals that would accept their papers. In addition, many of the journals run by major commercial publishers are run professionally and their unified graphical appearance gives them an identity. As scholarly communication moves from print to on-line, these publishers take advantage of emerging technological tools and standards to offer the research community ever better ways of presenting their content; they also energetically market their journals. PLoS, which was started with a view to fighting the commercial publishers, has spent US\$ 3 million on software development in 2013-14, and more than US\$ 413,000 on marketing and advertising in addition to expenses on promotion ${ }^{35}$.

The question, from the point of view of authors, is as follows: 'is it all right to spend such huge sums for getting papers published in OA journals?' No, says P. Balaram, former director of the Indian Institute of Science, Bengaluru. He believes that Indian researchers should not use government funds - money given for research - to subsidize non-Indian journals, and that the money spent on APC could be better spent on research per se, or on libraries ${ }^{36}$. According to Williams-Jones et $a l{ }^{37}$ 'for many sectors of academe', 'paying to publish' is ethically suspicious. Such an ethical concern has also been raised by Wilson and Golonka ${ }^{38}$. There are other voices from the global South opposed to OA through APC. Babini and Machin-Mastromatteo ${ }^{39}$ (Latin American Social Science Council) assert that paying huge sums as APC could increase the overall costs of research and financially undermine a nation's research and scientific publishing ecosystem. According to $\mathrm{Nilsen}^{40}$, paying to publish represents a new apartheid system, and that 'we need to move away from a system where someone decides who should have access to what'. For the sake of the global public good, Nilsen ${ }^{40}$ recommends that we should abandon the discriminative APC-based publishing practice and adopt $\mathrm{OA}$ through repositories.

The APC model is not serving the true purpose of OA, which aims to create a level playing field for access to research. The APC levied by PLoS Biology and PLoS Medicine is roughly equal to half of a month's salary of an assistant professor in the United States, but more than two months salary for an assistant professor in India.

Moreover, at a time when science is facing a funding crunch, it would be prudent for Indian researchers and research institutions to refrain from paying APC to journals. A few months ago, both Rao and Swaminathan lamented the shortage of funds for research ${ }^{41,42}$. More recently, the Ministry of Human Resource Development, Government of India (GoI) has announced some budgetary cuts for the Indian Institutes of Technology ${ }^{43}$ and the Ministry of Science and Technology, GoI, has informed 
CSIR laboratories to fund research by themselves and to convert ongoing projects into for-profit ventures ${ }^{44}$.

\section{What is the alternative model for making research $O A$ ?}

What is the alternative to publishing in paid OA journals? Balaram suggests that the authors could publish their papers without paying APC and still make them OA through interoperable institutional repositories ${ }^{36,45}$. Joshi $^{46}$ has explained the advantages of depositing one's papers in such repositories. Authors may wonder if making a paper available through such a repository is equivalent to publishing in an OA or hybrid OA journal. The answer is yes, very nearly. Journals may insist on an embargo and they may let the author deposit only the postprint (the refereed version). Experts such as Harnad would recommend the adoption of OA through repositories worldwide, so that institutions could cancel subscriptions and use the savings to pay for the much lowerpriced, affordable, sustainable OA journals ${ }^{47}$. Use of repositories is picking up around the world. According to Morrison', 'Bielefeld Academic Search Engine (BASE) repositories collectively added more than 4.7 million documents this quarter for a total of just under 89 million documents', and 'the number of journals actively participating in PubMed Central, making all content immediately freely accessible, and making all content open access, continues to grow'. During the last year arXiv grew by over 107,000 documents to over 1.1 million documents ${ }^{6}$.

\section{The current situation in India}

There are many OA journals in India, and more than 540 have been listed in DOAJ. These include journals published by leading academies, societies and government organizations such as CSIR-NISCAIR, DESIDOC, ICMR, and ICAR; these are free for both authors and readers. MedKnow, although part of a private publishing group, publishes a large number of OA titles, most of which again are free for both authors and readers. But not all Indian OA journals are on a single platform like SciELO. Apart from a few exceptions like MedKnow journals, others do not offer all the web features and metrics that the leading publishers offer, which is surprising considering the wealth of technological skills available in the country.

Another platform specifically designed to provide OA to journals published in developing countries is Bioline International, a not-for-profit partnership committed to providing OA to quality research journals, and reducing the South to North knowledge gap. Bioline currently supports 36 journals from 16 countries. The download statistics of Bioline journals (http://www.bioline.org.br/stats) is impressive. According to Barbara Kirsop, a founding member of Bioline International, 'Within a single month in 2016, some 1.5 million full text articles were downloaded - equivalent to approximately 18 million per annum - showing the value attached to publications resulting from research carried out in regions of the global south, often referred to as "the missing science", but nevertheless essential to achieve a global understanding in such areas as health and the environment' (pers. commun., 13 April 2016).

Organizations such as CSIR, DBT and DST have already adopted a policy of making research produced from their own laboratories, as well as research they support in other institutions, open access through placing the accepted papers in institutional OA repositories ${ }^{48,49}$. CSIR-URDIP, Pune has set up a central platform for OA repositories and harvesting from all three above-mentioned organizations (these may be accessed at http://www.csircentral. net/ and http://sciencecentral.in/). These repositories are interoperable and have adopted the best international practices. ICAR also has an OA policy, but it does not seem to have much traction ${ }^{50}$. There are also many institutional repositories (listed in http://roar.eprints.org/); some of them are well-populated but others are languishing, largely due to the indifference of scientists.

By contrast, China seems to have made considerable progress. It was only in 2014 that the Chinese Academy of Sciences (CAS) and the National Natural Science Foundation of China (NSFC) issued OA policies ${ }^{51}$. By mid-March 2016, the Open Repository of the NSFC included 135,000 research papers published between 1998 and 2015 by authors from 1305 institutions. These research papers have already been downloaded more than 669,000 times. CAS now has two OA portals, namely the Institutional Repository Grid of Chinese Academy of Sciences with content from 102 repositories, and the China Open Access Journal Portal with content from hundreds of journals ${ }^{52}$.

Latin America has witnessed the emergence of strong cooperative scholarly publishing ventures, such as SciELO (www.scielo.org) which hosts about 1250 journals, and Redalyc (www.redalyc.org) which hosts 1095 journals. Among these more than 2300 journals, 1300 do not charge APC while the others charge only a modest fee ${ }^{53}$. According to a SPARC report ${ }^{54}$, 'SciELO and Redalyc do raise the visibility and accessibility of the journals they host, particularly with their local communities. These types of networked meta-publishers allow for central governance of policies, procedures and controls, but are intentionally decentralized to support the development of local capacity and infrastructure ensuring greater sustainability and alignment with local policies and priorities'. With these efforts, Latin America has become a model for affordable OA journal publishing.

Even so, researchers in Latin America continue to publish a large proportion of their papers in non-OA journals. 
For example, as shown in Table 1, in the five years from 2010 to 2014 , more than $65 \%$ of papers from Brazil were published in non-OA journals. The simplest way to make the large volume of non-OA papers freely available is to set up many institutional repositories and populate them quickly. Efforts are already under way in several countries and indeed a network of repositories from nine countries is coordinated by LA Referencia (http:// lareferencia.redclara.net $/ \mathrm{rfr} /$ ), and there are legislations in place in Argentina, Mexico and Peru to make publicly funded research freely available through repositories ${ }^{55}$.

\section{What needs to be done?}

Compared with developments in Latin America and China, India is clearly lagging behind in making her research freely accessible. How can this be changed? We believe that making all research freely accessible through interoperable OA repositories is the ideal solution. According to Houghton and Swan ${ }^{56}$, till the time we reach an all-gold OA (OA through journals) world, green OA (OA through repositories) may well be the most immediate and cost-effective way to support knowledge transfer and enable innovation across the economy. We suggest the following actions:

1. Populate OA repositories that already exist, as empty and sparsely populated repositories will not reflect well on the research community.

2. Set up repositories in institutions where one does not exist. Academic and research librarians can play an important role in setting up and populating repositories.

3. Academic and research organizations (at the state and central levels, as well as apex bodies) which do not have an OA policy should adopt a policy similar to those of DBT, DST and CSIR and implement the same.

4. As part of the implementation, funding agencies and heads of organizations should have a compliance monitoring mechanism that would reward those who deposit their papers, and persuade those who do not.

5. If the policies of all agencies are aligned, it would bring about many advantages such as ease of compliance, optimization of workflow, and sharing of data and best practices ${ }^{57}$.

6. All organizations may join the CSIR-URDIP effort so that a nation-wide platform could emerge for OA repositories. Such resource sharing will not only result in enhanced efficiency and reduced overall costs but also, as demonstrated by HAL repository, France (https://hal.archives-ouvertes.fr/), facilitate 'coherent meta-data description, connection to national authority files, quicker take up of new technologies (e.g. visualisation and data mining) and better connection with international initiatives ${ }^{58}$.
7. Funding agencies and research organizations that have so far not been concerned about their funds being used to meet APC should stop supporting this practice.

8. A cadre of scholarly communication workforce should be developed for building institutional repositories and persuading researchers to upload materials.

\section{Conclusion}

If India and China follow the Latin American model of hosting all or most of their journals on a single decentralized platform and make as many journals as possible OA, and if India, China and Latin America vigorously promote a culture of $\mathrm{OA}$ repositories and encourage researchers to self-archive their publications, it would have a major impact on making science and scholarship open, not only in these regions, but around the world. All of this can happen only with the willing participation of the scientific community. As Harnad would say, 'Selfarchive unto others as you would have them self-archive unto you, 59 .

If, instead, researchers continue to pay publishers exorbitant APC, as Poynder $^{60}$ points out, there will soon be a crisis over the cost of APC, which would hit research the world over, but research in the developing world will be hit harder. As long as we continue to use APC-based journals, we cannot expect to make access to research affordable to all.

1. Harnad, S., A subversive proposal. In Scholarly Journals at the crossroads; A Subversive Proposal for Electronic Publishing (eds Okerson, A. and O'Donnell, J.), Association of Research Libraries, Washington, DC, 1995; http://babel.hathitrust.org/cgi/pt?id= mdp.39015034923758

2. Poynder, R., The subversive proposal at 20, an interview with Stevan Harnad, Open and Shut?, 2014; http://poynder.blogspot.in/ 2014/06/the-subversive-proposal-at-20.html (accessed on 22 March 2016).

3. Archambault, E., Amyot, D., Deschamps, P., Nicol, A., Rebout, L. and Roberge, G., Proportion of open access peer-reviewed papers at the European and world levels - 2004-2011, Science-Metrix, 2013; http://www.science-metrix.com/pdf/SM EC OA Availability 2004-2011.pdf

4. Solomon, D. J. and Björk, B. C., A study of open access journals using paper processing charges. J. Am. Soc. Inf. Sci. Technol., 2012, 63, 1485-1495; doi:10.1002/asi.22673

5. Crotty, D., Is it true that most open access journals do not charge an APC? Sort of. It depends. The Scholarly Kitchen, 2015; http://scholarlykitchen.sspnet.org/2015/08/26/do-most-oa-journalsnot-charge-an-apc-sort-of-it-depends/ (accessed on 22 March 2016).

6. Morrison, H., Dramatic growth of open access, 31 March 2016. Imag. J. Poetic Econ.; http://poeticeconomics.blogspot.in/2016/ 04/dramatic-growth-of-open-access-march-31.html (accessed on 13 April 2016).

7. http://road.issn.org/en/statistics (accessed on 13 April 2014).

8. Adams, C., Open access in Latin America: embraced as key to visibility of research, 2013; http://www.sparc.arl.org/news/openaccess-latin-america-embraced-key-visibility-research-outputs (accessed on 23 March 2016). 
9. Vessuri, H., Guédon, J. and Cetto, A. M., Excellence or quality? Impact of the current competition regime on science and scientific publishing in Latin America and its implications for development. Curr. Social., 2014, 62, 647-665; doi: 10.1177/0011392 113512839

10. Elsevier, Scopus content, 2016; http://www.elsevier.com/ data/assets/excel doc/0003/148548/title list.xlsx (accessed on 22 March 2016).

11. Turner, J., Opening up to open access research and publishing, 2015; http://stateofinnovation.thomsonreuters.com/opening-up-toopen-access-research-and-publishing (accessed on 22 March 2016)

12. Jamali, H. R. and Nabavi, M., Open access and sources of full-text papers in Google Scholar in different subject fields. Scientometrics, 2015, 105, 1635-1651; doi:10.1007/s11192-015-1642-2

13. Gunasekaran, S. and Arunachalam, S., Use of open access journals by Indian researchers. Curr. Sci., 2011, 101, 1287-1295.

14. Morrison, H., Salhab, J., Calvé-Genest, A. and Horava, T., Open access paper processing charges: DOAJ Survey May 2014. Publications, 2015, 3, 1-16; doi:10.3390/publications3010001

15. Wellcome Trust, Wellcome Trust and COAF Open Access Spend, 2014-15, 2016; http://blog.wellcome.ac.uk/2016/03/23/wellcometrust-and-coaf-open-access-spend-2014-15/ (accessed on 24 March 2016).

16. Research Councils UK, Review of the implementation of the RCUK Policy on open access, 2015; http://www.rcuk.ac.uk/ RCUK-prod/assets/documents/documents/Openaccessreport.pdf (accessed on 22 March 2016).

17. Research Councils UK, Independent review of the implementation of RCUK policy on open access: evidence from the University of Leeds, March 2015; http://www.rcuk.ac.uk/RCUK-prod/assets/ documents/oadocs/UniversityofLeeds.pdf (accessed on 22 March 2016).

18. University of Cambridge, Cambridge expenditure on APCs in 2014, Unlocking Research. 2015; https://unlockingresearch.blog. lib.cam.ac.uk/?p=79 (accessed on 22 March 2016)

19. Björk, B. and Solomon, D., Developing an effective market for open access paper processing charges. 2014; http://www. wellcome.ac.uk/stellent/groups/corporatesite/@policy_communications/documents/web_document/wtp055910.pdf (accessed on 22 March 2016).

20. Gerritsma, W., The costs for going gold in the Netherlands, WoW! Wouter on the Web, 2014; http://wowter.net/2014/03/05/costsgoing-gold-netherlands/ (accessed on 22 March 2016).

21. Rieck, K., Haslinger, D., Meischke-Ilic, S., Kirindi-Hentschel, Ü. and Reckling, F., Analysis of the publication costs of the Austrian Science Fund (FWF) in 2015, Figshare, 2016; doi:10.6084/ m9.figshare. 3180166

22. Wang, L. L., Liu, X. Z. and Fang, H., Investigation of the degree to which papers supported by research grants are published in open access health and life sciences journals, Scientometrics, 2015, 104, 511-528; doi:10.1007/s11192-015-1624-4

23. Poynder, R., The OA interviews: Michael Eisen, co-founder of the Public Library of Science. Open and Shut, 2012; http://poynder.blogspot.in/2012/02/oa-interviews-michael-eisenco-founder.html (accessed on 22 March 2016).

24. Wheatly, S., Comparison of BioMed Central APCs from 2010 2016. Sustaining the Knowledge Commons, 2016; https:// sustainingknowledgecommons.org/2016/04/13/comparison-ofbiomed-central-apcs-from-2010-2016/ (accessed on 15 April 2016).

25. Starczewsk, M., Open access will remain a half revolution, $\mathrm{CeON}$ Otwarta Nauka, 2016; http://otwartanauka.pl/in-english/expertson-open-access/open-access-will-remain-a-half-revolutioninterview-with-richard-poynder (accessed on 22 March 2016).

26. $\mathrm{SCOAP}^{3}-$ Sponsoring Consortium for Open Access Publishing in Particle Physics; https://scoap3.org/scoap3journals/ (accessed on 22 March 2016).
27. Rosenzweig, M. L., Protecting access to scholarship: we are the Solution. 2000; http://www.evolutionary-ecology.com/citizen/ spring00speech.pdf (accessed on 27 March 2016).

28. Laakso, M. and Björk, B., Anatomy of open access publishing: a study of longitudinal development and internal structure. $B M C$ Med., 2012, 10, 124; doi:10.1186/1741-7015-10-124

29. Journal declarations of independence. Open Access Directory; http://oad.simmons.edu/oadwiki/Journal declarations of indepen dence (accessed on 27 March 2016).

30. Greenberg, J., Editors of the journal Lingua protest - quit in battle for open access. Wired, 2015; http://www.wired.com/2015/ 11/editors-of-the-journal-lingua-protest-quit-in-battle-for-openaccess/ (accessed on 22 March 2016).

31. Gowers, T., Discrete analysis - an arXiv overlay journal. Gower's Weblog, 2015; https://gowers.wordpress.com/2015/09/10/discreteanalysis-an-arxiv-overlay-journal/ (accessed on 22 March 2016).

32. Rooryck, J., Editorial. Glossa: A J. Gen. Linguist., 2016, 1, 1-3, doi:http://dx.doi.org/10.5334/gjgl.91

33. Belluz, J., This renowned mathematician is bent on proving academic journals can cost nothing. Vox, 2016; http://www.vox. com/2016/3/4/11160540/timothy-gowers-discrete-analysis (accessed on 27 March 2016).

34. Alberts, B., Impact factor distortions. Science, 2013, 340, 787; doi:10.1126/science. 1240319

35. Public Library of science financial statements, 31 December 2014; https://www.plos.org/wp-content/uploads/2013/12/PLoSDec14AR-Final.pdf

36. Jayaraman, K. S., Q\&A: open archives - the alternative to open access, SciDev.net, 2008; http://www.scidev.net/global/ communication/feature/q-a-open-archives-the-alternative-to-openaccess.html (accessed on 22 March 2016).

37. William-Jones, Pipon, J.-C.B., Smith, E. and Boulanger, R., Ethical challenges of open access publishing - for many sectors of academe, 'paying to publish' is ethically suspicious. 2014; http:// www.universityaffairs.ca/opinion/in-my-opinion/ethical-challengesof-open-access-publishing/ (accessed on 22 March 2016).

38. Wilson, D. A. and Golonka, S., The high price of open access. Notes from two scientific psychologists, 2016; http://psychsciencenotes.blogspot.in/2016/03/the-high-price-of-open-access.html (accessed on 22 March 2016).

39. Babini, D. and Machin-Mastromatteo, J. D., Latin American science is meant to be open access - initiatives and current challenges. Inf. Dev., 2015, 31, 477-481; doi:10.1177/0266666915601420

40. Nilsen, R., Europe's open access champions, 2015; http:// openscholarchampions.eu/champions/fightacademicapartheid/ (accessed on 27 March 2016).

41. C. N. R. Rao warns govt: funds drought may push scientists out of science. The Indian Express, 8 November 2015; http://indianexpress.com/paper/india/india-news-india/cnr-rao-warns-govt-fundsdrought-may-push-scientists-out-of-science/\#sthash.17kqwllJ.dpuf (accessed on 22 March 2016).

42. Krishnan, V., Fund crunch has hit research in 32 institutions: ICMR chief. The Hindu, 15 January 2016; http://www.thehindu. com/news/national/fund-crunch-has-hit-research-in-32-institutionsicmr-chief/paper8108880.ece (accessed on 22 March 2016).

43. Malhotra, A., IIT-K faces fund crisis, demands for more grant from Ministry of HRD, Times of India, 13 March 2016; http://timesofindia.indiatimes.com/city/kanpur/IIT-K-faces-fundcrisis-demands-for-more-grant-from-Ministry-of-HRD/papershow/ 51380722.cms (accessed on 22 March 2016).

44. Krishnan, V. and Peri, D., Govt. tells labs: fund research by yourself. The Hindu, 28 October 2015; http://www.thehindu.com/ news/national/govt-tells-labs-fund-research-by-yourself/paper7811265.ece (accessed on 22 March 2016).

45. Dane, T., Professor Balaram talks open access. 15 November 2011; http://cis-india.org/openness/professor-balaram-talks-openaccess (accessed on 27 March 2016). 
GENERAL ARTICLES

46. Joshi, N. V., Institutional e-print archives: liberalizing access to scientific research. Curr. Sci., 2005, 89, 421-422; http://www.currentscience.ac.in/Downloads/download_pdf.php?tit leid=id $08903 \quad 0421 \quad 0422 \_0$ (accessed on 27 March 2016).

47. Poynder, R., Where are we, what still needs to be done? Stevan Harnad on the state of open access, Open and Shut?, 2013; http://poynder.blogspot.in/2013/07/where-are-we-what-still-needsto-be.html (accessed on 27 March 2016).

48. CSIR open access mandate; http://www.csircentral.net/mandate. pdf (accessed on 27 March 2016)

49. DBT-DST open access policy, 2015; http://dst.gov.in/news/dbtdst-open-access-policy (accessed on 27 March 2016).

50. ICAR adopts open access policy; http://icar.org.in/en/node/6609 (accessed on 27 March 2016).

51. Van Noorden, R., Chinese agencies announce open-access policies. Nature, 2014, doi:10.1038/nature.2014.15255

52. Liping, K., Open access and open research data in China. Eifl blog, 2016; http://www.eifl.net/blogs/open-access-and-open-researchdata-china (accessed on 27 March 2016).

53. Babini, D., Repositories as key players in non-commercial open access - a developing region perspective. In COAR-SPARC Conference, Portugal, 15-16 April 2015, http://www.slideshare.net/ CLACSOredbiblio/repositories-as-key-players-in-noncommercialopen-access-a-developing-region-perspective (accessed on 24 March 2016).

54. SPARC, Open access in Latin America: a paragon for the rest of the world. 2015; SciELO in perspective; http://blog.scielo.org/en/ 2015/08/18/open-access-in-latin-america-a-paragon-for-the-rest-ofthe-world-originally-published-in-the-sparc-blog/ (accessed on 27 March 2016).

55. Starczewski, M., LA Referencia - South American Open Science network. ceonOtwartaNauka, 2015; https://otwartanauka.pl/ analysis/nauka-otwartosc-swiat/la-referencia-poludniowoamerykanskasiec-otwartej-nauki/la-referencia-south-american-open-sciencenetwork?showall=1\&limitstart $=($ accessed on 27 March 2016).

56. Houghton, J. and Swan, A., Planting the green seeds for a golden harvest: comments and clarifications on 'going for gold'. D-Lib Mag., 2013, 19, 1/2; doi:10.1045/january2013-houghton

57. Scholarly Publishing and Academic Resources Coalition, Open access and research funders: a report on challenges, opportunities, and collaboration. 2016; http://sparcopen.org/wp-content/uploads/ 2016/04/RWJF-SPARC-public-report.pdf (accessed on 15 April 2016).

58. Baeten, J., Estraillier, P., Kirchner, C., Moatti, A. and Romary, L., Open Access in Japan - a multi-institutional perspective (Research Report) Ambassade de Franceau Japon, 19 March 2016.

59. Harnad, S. and Swan, A., India, open access, the law of karma and the golden rule. DESIDOC J. Libr. Inf. Technol., 2008, 28, 35-40; doi:10.14429/djlit.28.1.150

60. Poynder, R., Open access: what price affordability? eCancer, 2014, 41; doi:10.3332/ecancer.2014.ed41

ACKNOWLEDGEMENT. We thank Peter Suber, Director, Harvard Office for Scholarly Communication, USA and Ms Barbara Kirsop, Electronic Publishing Trust for Development, UK for their valuable comments.

Received 29 April 2016; accepted 1 September 2016

doi: $10.18520 / \mathrm{cs} / \mathrm{v} 112 / \mathrm{i} 04 / 703-713$ 